\title{
Correlation between Asymptomatic Bacteriuria and HIV-1 Viral Load Level and CD4 Count in Pregnant Women on Antiretroviral Therapy in N'djamena (Chad)
}

\author{
Adoum Fouda Abderrazzack ${ }^{1,2}$, Mounerou Salou ${ }^{3,4^{*}}$, Akouda Patassi5 ${ }^{5}$, Degninou Yehadji6 \\ Yaovi Ameyapoh ${ }^{2 *}$ \\ ${ }^{1}$ Service de Laboratoire et médicaments du Programme Sectoriel de lutte contre le sida et les Infections \\ Sexuellement Transmissibles, N'djamena, Tchad \\ ${ }^{2}$ Laboratoire de microbiologie et de contrôle de qualité de denrées alimentaires, Ecole Supérieure des \\ Techniques Biologiques et Alimentaires, University of Lomé, Lomé, Togo \\ ${ }^{3}$ Département des sciences fondamentales, Faculty of Health Science, University of Lomé, Laboratory of \\ Microbiology CHU Sylvanus OLIMPYO, Lomé, Togo \\ ${ }^{4}$ Centre de biologie moléculaire et d'immunologie, FSS/UL, Lomé, Togo \\ ${ }^{5}$ Service des maladies infectieuses, CHU Sylvanus OLIMPYO, Lomé, Togo \\ ${ }^{6}$ Ministry of Health, Lomé, Togo \\ Email: "mounerous@gmail.com, ”ameyapoh.blaise@gmail.com
}

Received 20 October 2015; accepted 5 December 2015; published 8 December 2015

Copyright ( 2015 by authors and Scientific Research Publishing Inc.

This work is licensed under the Creative Commons Attribution International License (CC BY).

http://creativecommons.org/licenses/by/4.0/

(c) (i) Open Access

\section{Abstract}

A cross-sectional study was conducted at the "Centre de l'Appui Psycho-Médico-Social (APMS)" which is a centre for Psychological and Medical Support in N'Djamena (Chad) from January to March 2014. The aim of this study was to evaluate the correlation between asymptomatic bacteriuria (ASB) and viral load level and CD4 count in seventy-six (76) HIV-1 infected pregnant women on antiretroviral therapy (ART). Urine culture and bacteria identification were performed by using a chromogenic culture medium (UriselectR4). $\mathrm{T} \mathrm{CD4} 4^{+}$lymphocytes count and viral load measurement were done respectively on PIMA ${ }^{\mathrm{TM}}$ test and Abbott $\mathbf{m} 2000$ RealTime HIV-1. In this study, 25 (32.9\%) pregnant women were carrying ASB and major bacteria; Escherichia coli and Streptococcus agalactiae known to cause neonatal meningitis to newborns were identified. Bacteria were isolated mainly in women with CD4 lymphocytes $<200$ cells $/ \mathrm{mm}^{3}(60 \%)(15 / 25)$ and a viral load $>$ $3 \log (70 \%)(19 / 25)$. Besides the prevention of mother to child transmission of HIV, which remains a goal, it is important to prevent also the transmission of other microorganisms causing neonatal

*Corresponding authors.

How to cite this paper: Abderrazzack, A.F., Salou, M., Patassi, A., Yehadji, D. and Ameyapoh, Y. (2015) Correlation between Asymptomatic Bacteriuria and HIV-1 Viral Load Level and CD4 Count in Pregnant Women on Antiretroviral Therapy in N'djamena (Chad). World Journal of AIDS, 5, 308-312. http://dx.doi.org/10.4236/wja.2015.54033 
infections. Our findings support the needs to do bacteriological analysis of urine in every HIV-infected pregnant woman at least in late pregnancy.

\title{
Keywords
}

\author{
Pregnant Women, Asymptomatic Bacteriuria, Lymphocyte CD4, Viral Load
}

\section{Introduction}

Successful antiretroviral therapy (ART) in people living with HIV (PLHIV) may leads to an undetectable viral load (VL) after 6 months treatment and be maintained undetectable or below 50 copies/ml later [1] [2]. Besides this antiretroviral drugs' effectiveness, it turned out that the immunosuppression state induced by the Human Immunodeficiency Virus (HIV) infection seems to increase asymptomatic bacteriuria (ASB) in HIV infected pregnant women in about $6 \%$ to $20 \%$ of cases [3]-[7]. ASB is a urinary tract infection without clinical signs [8] [9]. In this case, urine culture is recommended at the first prenatal visit [10].

This study is conducted to evaluate the correlation between ASB and CD4 count and HIV-1 viral load in a cohort of HIV infected pregnant women followed-up for prevention of mother to child transmission (PMTCT) in N'djamena (Chad).

\section{Material and Methods}

\subsection{Study Site and Population}

This was a cross sectional study conducted from January $1^{\text {st }}$ to March $31^{\text {st }}$, 2014 among pregnant HIV-1 infected women on ART and followed-up at Centre de l'Appui Psycho-Médico-Social (APMS) of Ndjamena (Chad), a health center dedicated to people living with HIV. Pregnant women attending the site for antenatal care and not presenting any symptoms of a urinary tract infection (UTI) and not taking antibiotics for any current infection, who gave their oral consent, were included in the study.

\subsection{Samples Collection}

Clean-catch midstream urine samples were collected in sterile universal containers from pregnant women. They were instructed on how to collect samples and the need for prompt delivery to the laboratory the next day following their inclusion. About $10 \mathrm{ml}$ venous blood were collected at the elbow on 2-Ethylene Diamine Tetra Acetate (EDTA) tubes.

\subsection{Laboratory Analyses}

Urine samples were seeded within 30 minutes to 1 hour after the collection onto Uriselect ${ }^{\mathrm{TM}} 4$ (Bio-Rad, France) a chromogenic non-selective agar medium consisted of a rich nutrients base of four peptones ensuring the growth of all the germs of the urinary tract, two chromogenic substrates for the detection of bacterial enzymes ( $\beta$-galactosidase and $\beta$-glucosidase), and tryptophan for the detection tryptophanase's activity (indole production) and tryptophan deaminase (TDA). Cultures were incubated at $37^{\circ} \mathrm{C}$ for 24 hours. Bacterial colonies growing on the agar after the incubation period were identified as described by the Uriselect ${ }^{\mathrm{TM}} 4$ user guide.

CD4 count was performed on whole blood using Alere Pima ${ }^{\mathrm{TM}}$ (Alere Technologies GmbH, Germany), a point-of-care device. Viral load samples were brought to the Virology Unit of the General Reference Hospital of N'Djamena (HGRN, Chad), using an insulated refrigerated container at $4^{\circ} \mathrm{C}$. On site, two plasma aliquots of about $1 \mathrm{ml}$ were made and stored at $-20^{\circ} \mathrm{C}$ until the VL test was carried out. The VL was determined using Real-Time-Reverse Transcription Polymerase Chain Reaction (Real-Time RT-PCR) method using Abbott m2000 RealTime System (Abbott Laboratories, Abbott Park, Illinois, USA).

\subsection{Demographic and Clinical Information}

Socio-demographic information and antiretroviral treatment histories were collected using a standardized form. 


\subsection{Ethical Considerations}

The study was approved by the ethical committee of the Centre de l'Appui Psycho-Médico-social (APMS) of Ndjamena (Chad) Coordination of the Psychological and Medical Support Unite (APMS) under the reference No. 196/PR/PM/MSPASSN/DG/PSLS-IST/PMSS/2013.

\subsection{Statistical Analysis}

Continuous variables were compared using the Wilcoxon rank-sum test, and comparison between two categorical variables was performed using the Chi-square test and Fisher's exact test when cell values were less than 5. For all analyses p-value of less than or equal to 0.05 was used to determine statistical significance.

\section{Results and Discussions}

During the 3-month study period, 76 HIV-infected pregnant women were included in the study. They aged 15 to 45 years with a median of 30 years (IQR) [22 - 28 years]. The gestational age ranged from 5 to 9 months. The women were treated by a combination ART (cART) represented by (Tenofovir (TDF) + Lamivudine (3TC) + Efavirenz (EFV)) (71.03\%). The median duration on ART was 4 months. The socio-demographics characteristics of study population are summarized in Table 1.

We found 25 (32.9\%) pregnant women of the study population carrying ASB and none of them carried more than one bacteria strain in the urinal tractus. They aged 24 to 35 years with a median of 34.5 years. All age groups were concerned by the ASB. The ASB prevalence was 32.9\% CI95\% [22.3\% - 43.5\%] and it was higher than $18.6 \%$ reported from a similar study conducted in South Africa [11].

Among, 25 women carrying ASB, 15 (60\%), 5 (20\%), 2 (8\%) and 3 (12\%) carried Enterobacteria, mainly Escherichia coli (11/15), Streptococcus agalactiae also known a Group B Streptococci (GBS), Staphylococcus aureus and Candida albicans respectively (Table 2). Among women with ASB, 14 (56\%) had CD4 count < 200 cell/ $\mathrm{mm}^{3}$ and 18 (72\%) had VL > 1000 copies/ml (3log copies/ml) (Table 2). Amongst pregnant women without

Table 1. Characteristics of study population.

\begin{tabular}{|c|c|c|}
\hline Characteristics & $\mathbf{n}$ & $(\%)$ \\
\hline \multicolumn{3}{|l|}{ Age Group (Years) } \\
\hline $15-24$ & 29 & 38.16 \\
\hline $25-34$ & 45 & 59.21 \\
\hline $35-45$ & 2 & 2.63 \\
\hline \multicolumn{3}{|l|}{ Parity } \\
\hline Nulliparous & 11 & 14.47 \\
\hline Primiparous & 27 & 35.53 \\
\hline Multiparous & 38 & 50 \\
\hline \multicolumn{3}{|l|}{ Marital Status } \\
\hline Married & 53 & 69.74 \\
\hline Divorced & 16 & 21.05 \\
\hline Single & 5 & 6.58 \\
\hline Widow & 2 & 2.63 \\
\hline \multicolumn{3}{|l|}{ Occupation } \\
\hline Housewive & 43 & 56.58 \\
\hline Trader & 17 & 22.36 \\
\hline Seller & 9 & 11.84 \\
\hline University Student & 7 & 9.22 \\
\hline
\end{tabular}


Table 2. Distribution of isolated pathogens depending on CD4 and viral load values.

\begin{tabular}{|c|c|c|c|c|c|c|}
\hline $\begin{array}{l}\text { Immunologic and } \\
\text { virologic values }\end{array}$ & $\begin{array}{c}\text { E. coli } \\
(\mathrm{n}=11)\end{array}$ & $\begin{array}{c}\text { Streptococcus } \\
\text { agalactiae }^{*} \\
(\mathbf{n}=5)\end{array}$ & $\begin{array}{l}\text { Staphylococcus } \\
\text { aureus }(\mathrm{n}=2)\end{array}$ & $\begin{array}{c}\text { Klebsiella } \\
\text { pneumoniae } \\
(\mathrm{n}=2)\end{array}$ & $\begin{array}{c}\text { Enterobacter } \\
\text { cloacea } \\
(\mathbf{n}=2)\end{array}$ & $\begin{array}{c}\text { Candida } \\
\text { albicans } \\
(\mathrm{n}=3)\end{array}$ \\
\hline \multicolumn{7}{|l|}{ CD4 count per $\mathrm{mm}^{3}$} \\
\hline <200: n (\%) & $6(54.5)$ & $3(60)$ & $1(50)$ & $2(100)$ & $-^{* *}$ & $2(75)$ \\
\hline 200 - 500: n (\%) & $4(36.4)$ & $2(40)$ & $1(50)$ & $0(0)$ & $2(100 \%)$ & $1(25)$ \\
\hline >500: n (\%) & $1(9.1)$ & - & - & - & - & \\
\hline \multicolumn{7}{|l|}{ VL $(\log 10)$ copies/ml } \\
\hline <1.7 log: n (\%) & - & - & - & - & & - \\
\hline <3 log: n (\%) & $4(36.7)$ & $1(20)$ & - & - & $11(50)$ & $1(25)$ \\
\hline >3 log: n (\%) & 7 (63.6) & $5(80)$ & $2(100)$ & $2(100)$ & $11(50)$ & $2(75)$ \\
\hline
\end{tabular}

*Streptococcus agalactiae or Group B Streptococci; ** Bacteria not found.

ASB 19 (37.3\%) had CD4 $<200$ cell/mm³ and 4 (7.8\%) had VL > 1000 copies/ml. The difference between the rates of CD4 count below $200 \mathrm{cell} / \mathrm{mm}^{3}$ according to bacteriuria is not statistically significant $(p=0.294)$, there is no correlation between ASB and CD4 rates $(\mathrm{RR}=1.66)$. The difference between the rates of pregnant women with VL above 1000 copies/ml (virological failure) according to bacteriuria is statistically significant $(p=0.028$ ), there is a correlation between virological failure (VL > 1000 copies $/ \mathrm{mm}^{3}$ ) and ASB in HIV-1-infected pregnant women $(\mathrm{RR}=4.66)$.

Of 25 uropathogens strains isolated from urine, 14 (56\%) were isolated in HIV-1 infected pregnant women with CD4 count values below 200 cells/ $\mathrm{mm}^{3}$ and 19 (76\%) were isolated from women with viral load value above $3 \log$ (1000 copies/ml) (Table 2).

Although results showed that most of HIV infected pregnant women with ASB had CD4 count below $200 / \mathrm{mm}^{3}$, some studies suggested that the level of CD4 count below $200 / \mathrm{mm}^{3}$ or higher or equal to $200 / \mathrm{mm}^{3}$ did not have a major influence on ASB. However, viral load would have a decisive role in the development of ASB among this vulnerable group [12]. A study conducted in South Africa demonstrated a high incidence (18.6\%) of ASB among pregnant HIV-positive women compared to those whom were HIV-negative (12.9\%) (11). But in our previous study conducted among HIV-negative pregnant women in Lomé (31.03\%) [13], we found an ASB rate similar to what we are reporting here in HIV infected pregnant women in N'djamena. These findings support conclusions from other studies, which reported that pregnancy is a major risk factor for the development of ASB [13] [14].

Although a few studies have been conducted on this subject in sub-Saharan Africa, few of them discussed the value of urinary tract infections screening during pregnancy [15] [16].

\section{Conclusion}

In this study, Escherichia coli and Streptococcus agalactiae-major bacteria known to cause neonatal meningitis to newborns, were isolated. Thus, evidence gathered on ASB in pregnant women infected with HIV represents a milestone for recommendation of systematic screening of urinary tract infections in Chad. The results also highlight the needs to reach viral suppression in order to reduce the risk of ASB in pregnant women.

\section{Acknowledgements}

We are grateful to the Embassy of France in Chad and Togo for their support. We express our deep gratitude to Dr. Alhassane BA (International consultant), Dr. Goudjo ABDON (Advisor to the Ministry of Public Health of Chad), Dr. Mahamat SALEH and Dr. Mahamat NOUR AGUID respectively Coordinator and Physician responsible for the care of PLHIV in (centre de l'Appui psycho medico social), and all laboratory technicians, pharmacists, counselors and support staff of the center. 


\section{References}

[1] Palella, F.J., Delaney, K.M., Moorman, A.C., Loveless, M.O., Fuhrer, J., Satten, G.A., Aschman, D.J. and Holmberg, S.D. (1998) Declining Morbidity and Mortality among Patients with Advanced Human Immunodeficiency Virus Infection. The New England Journal of Medicine, 13, 853-860. http://dx.doi.org/10.1056/NEJM199803263381301

[2] Hocini, H. and Andreoletti, L. (2009) Méthodes d'analyse et de suivi de l'infection par les virus de l'immunodéficience humaine. Revue Francophone Des Laboratoires, 9, 39-48. http://dx.doi.org/10.1016/S1773-035X(09)70308-9

[3] Evans, J.K., McOwen, A., Hilman, R.J. and Foster, G.E. (1995) Incidence of Symptomatic Urinary Tract Infections in HIV Seropositive Patients and Use of Cotrimoxasole as Prophylaxis against Pneumocystics Carina Pneumonia. Genitourinary Medicine, 2, 120-122.

[4] Johnson, J.R., Roberts, P.L. and Stamm, W.E. (1987) P Fimbriae and Other Virulence Factors in Escherichia coli Urosepsis: Association with Patients’ Characteristics. Journal of Infectious Diseases, 4, 225-229. http://dx.doi.org/10.1093/infdis/156.1.225

[5] Hoepelman, A.I.M., Van, M.B. and Van den Broek, P.J. (2012) Bacteriuria in Men Infected with HIV-1 Is Related to Their Immune Status (CD4+ Cell Count). AIDS, 5, 179-184.

[6] Heyns, C.F. and Fisher, M. (2005) The Urological Management of the Patient with Acquired Immunodeficiency Syndrome. BJU International, 95, 709-716. http://dx.doi.org/10.1111/j.1464-410X.2004.05435.x

[7] Widmer, T.A., Theron, G. and Grove, D. (2010) Prevalence and Risks of Asymptomatic Bacteriuria among HIV-Positive Pregnant Women. Southern African Journal of Epidemiology \& Infection, 4, 28-32.

[8] Mauroy, B., Beauscart, C., Biserte, J., Colombeau, P., Delmans, V., Fendller, J.P., et al. (1996) L’infection urinaire chez la femme enceinte. Progrès en urologie, 15, 607-622.

[9] Rubin, R.H., Shapiro, E.D., Andriole, V.T., Davis, R.J. and Stamm, W.E. (1992) Evaluation of New Anti-Infective Drugs for the Treatment of Urinary Tract Infection. Clinical Infectious Diseases, 11, S216-S227. http://dx.doi.org/10.1093/clind/15.supplement_1.s216

[10] Hall, D.R., Theron, G.B. and Engelke, E. (1991) Evaluation of Dipstick Screening of Antenatal Patients for Asymptomatic Bacteriuria. Southern African Journal of Epidemiology and Infection, 6, 64-70.

[11] Laker, S.C., Pattinson, R.C. and Lmbard, H. (2004) Does HIV Status Affect the Prevalence of Asymptomatic Bacteriuria in Pregnancy? 23rd Conference on Priorities in Perinatal Care in Southern Africa, Abstract.

[12] Park, J.C., Buono, D. and Smith, D.K. (2002) Urinary Tract Infections in Women with or at Risk of Human Immunodeficiency Virus Infection. American Journal of Obstetrics \& Gynecology, 187, 581-588. http://dx.doi.org/10.1067/mob.2002.125894

[13] Hooton, T.M., Scholes, D., Stapleton, A.E., Roberts, P.L., Winter, C., et al. (2000) A Prospective Study of Asymptomatic Bacteriuria in Sexually Active Young Women. New England Journal of Medicine, 5, 992-997. http://dx.doi.org/10.1056/NEJM200010053431402

[14] Magnus, S.A., Hambleton, I.R., Moosdeen, F. and Serjeant, G.R. (1999) Recurrent Infections in Homozygous Sickle Cell Disease. Archives of Disease in Childhood, 4, 537-541. http://dx.doi.org/10.1136/adc.80.6.537

[15] Dietrich, M., Hoosen, A.A., Moodley, J. and Moodley, S. (1992) Urogenital Tract Infections in Pregnancy at King Edward VIII Hospital, Durban, South Africa. Genitourinary Medicine, 2, 39-41. http://dx.doi.org/10.1136/sti.68.1.39

[16] Nnatu, S., Essien, E.E., Akinkugbe, A. and Odum, C.U. (1989) Asymptomatic Bacteriuria in Pregnant Nigerian Patients. Clinical and Experimental Obstetrics and Gynecology, 4, 126-130. 